\title{
Paul and Hard Work (2 Thessalonians 3:6-10): A Christian Approach to Social and Economic Development
}

\author{
Chibuzo I. Nwanguma \\ http://dx.doi./org/10.4314/ujah.v18i1.10
}

\begin{abstract}
Hard work though misconstrued, misrepresented and misappropriated in some quarters, is a sine qua non to development. Wherever or whenever the concept of development is talked about, whether social, economic, or biological, hard work of any sort is always implied. In this work which attention is essentially drawn to Christian approach to social and economic development, Paul's model is the standard of consideration in the deliberation. As has always been the case with all biblical writings which this work will not be an exception, the selected passage will be critically analysed as some related terms will be explained prior to the analysis. The results of these will be basis for appraisal of the Nigerian society as regards its developmental programmes in the nation as to evaluate and ascertain the extent to which Pauline model and Christianity, in particular, has affected the nation. The result shall also be used as tool for recommendation where lapses are observed.
\end{abstract}

Keywords: Paul, Hard work, Christian, Social and Economic, Development

\section{Introduction}

Development or improvement is a common feature wherever there is life or existence, whether biological, social or economic etc. God Himself, in biblical perspective, seems to expect this of any 
creature of His. This is seemingly evident in His attitude in Eden at the very beginning of His relationship with humankind. The author of Genesis narrates that God always came down, perhaps, daily at a particular time to especially know how humanity fared - if there were improvements in whatever sphere either horizontally amongst themselves and the environment in which they found themselves in, or vertically in regard to their relationship with Him (cf. Genesis 3:8-9). In the same vein, the Gospels authenticate this phenomenon in some regards. For instance, Jesus, in His Luke's parable of the fig tree, portrays this assertion. There, the owner of a vineyard had expected some improvements (good developments, bearing of fruits) of a particular tree for three consecutive years to no avail and wanted it "cut down" but the "vinedresser" quickly intervened by pleading for the grace of "one year" when he would have to "dig about it and put on manure" (Luke 13:6-9) for the desired result.

In family setting, for instance, parents monitor the developmental states, stages or conditions of their wards. At the very beginning of the life of a child (say within the first three months or so) developments of all sorts, either physical or cognitive etc. are expected to be daily (Elliot, 2001:31). Where such wants in a child, the parents get worried. The implication here is that the child lacks, as it were, certain natural substances that the body system could naturally and synergistically apply to enhance the holistic development of the child. Where such is the case, the parents in question will normally seek the assistances of the requisite experts that could professionally help to resolve the malady.

The synergistic activity that could be want in the child's body system that brings about deficiencies in the child's developmental processes could be likened to deficiency in 
organisational collaboration as regards social cum economic activities that could inhibit developmental processes in a nation such as Nigeria. And the timely intervention of the parents in soliciting the assistance of experts in order to take care of that which had hitherto inhibited the developmental processes in the child could be likened to any awareness or sensitizing activities of concerned fellows (experts in their rights) in order to ameliorate the developmental conditions in the land and such is the endeavour of this work as Paul's model (2 Thessalonians 3:6-10) is consulted and applied to the modern man.

\section{Clarifications of Important Terms}

There are some terms that require peculiar attentions especially in relation to the subject matter of this work. The terms in question are social, economic, and development. Though the words may be familiar to any English speaker, to some extent, the usage in this work could be different in some regards, thus, the explanations.

The word social, is cultural in perspective and has much to do with how people go about their lives' affairs in the environments they find themselves. It is particularly adjectival in nature, that is, it is descriptive and explanatory in nature. This is particularly why it can always naturally adapt itself to suit any application in context. For example, it is said that it relates to human society and how it is organized as well as relating to the way in which people in groups behave and interact among themselves. Besides, looking at the term from its cultural perspective, Dzurgba taking it from the etymological stand point explains that the term "was coined from a Latin word cultura which literally means "cultivation of the soil," and that "in a comparative manner," the term could mean "the cultivation of the human mind." Thus, the etymological meaning of culture was a 
focus on the process of cultivating the mind" and in such a sense, "some people were described as cultured men, just as it could be said about some men today that are educated" $(2009,12)$. Further, he said gradually, the concept of culture moved from its classical origins to social condition, and from there took upon itself several meanings. Culture became associated with works of arts, of intellectual works, articulation of ethical principles, religion, politics and trade. Thus, the term "social," can be used interchangeably with its cognate term, "cultural" in context given the picture it is painted in the text above in the sense that most things that are anything social have some significant degrees of cultural undertone; be it social dance, social life, social attitude etc.

Whenever and wherever the term economics is mentioned, one thing comes to people's mind. There is always this phobia of an attempt to control activities of people especially in terms of freedom of access to some public belongings particularly where there has been unprecedented degree of uncontrolled wastages and what the bible terms riotous spending (cf. Luke 15:13). Simply put it is about how society addresses or manages the problem of scarcity. A group of economic experts in their introductory statements to their book state that "it is not just about incomes, prices and money" (David and Fischer, 2005:1) but seeks to advise the society on how best to make choices between competing needs. And, the need to make choices strictly entails sound and sincere planning hence the need of Christian approach. This assertion quickly reminds one of Joseph's interpretations of Pharaoh's dreams, the advice to him, and the outcome (cf. Genesis 41:17-57). As says another group of economic experts, many of the world's most pressing problems are economic in nature (Baumol and Blinder et al, 2006: 3). If most of the world's pressing problems are economic in essence, this work is then a round peg in a round 
hole in that it is set to apply Christian approach to such problems as in the olden days; its essential thrust is an appraisal as to how the society has hitherto grappled with the various needs and wants in the land severally and individually.

The term development as a word, calls for one's attention in this study. Like any of such terms, in context, it could be explained just to suit an intention in perspective. The word in the first instance derives from its verb "develop." Basically, to develop means to grow larger or to effect changes over a period of time. The noun form "development" means increase in size or condition of being developed and such would necessarily mean that a new stage is being reached "as a consequence of developing" Okeafor, 2004:300). The question then is how can hard work effect social and economic development in the society? Although nothing has been said about hard work per se, but even from medical cum biological points of view, it enhances development in any living organism. For instance, physical and health education is encouraged in school system for so many reasons among which is to achieve proper development Adeyeye, 2008:6).To a great extent, hard work, whichever way one perceives it, entails exercises of the general human body systems and by extension, the entire society hence the enhancement of the developmental processes of the general society.

\section{Background and General Analysis to the Text Background}

Paul in his characteristic manner wrote this letter to attend to some issues in the Thessalonian church. A little while after (Though, some argue that the letter was a pseudepigraph, that is, a letter written authoritatively in Paul's name to maintain apostolic traditions in later period, perhaps during the last two decades of the 
first century) he had written his first letter to the church expressing his happiness and joy towards them over their repentance and zeal in their new found faith which came as a result of his ministration to them, news came to him that some people (some of Thessalonian Christians) had lapsed into some kind of confusions with regard to the second coming of Jesus "thinking that the sudden coming (1 Thess. 5:3) implies his immediate coming" (Henrikson, 330). As a result idleness became the order of the day on the part of some while others resorted to leisure that was considered more conducive to the development of the mind and spirit leading to disorderliness in the community. Paul therefore wrote to correct this confusion and wrong notion of some about the Parousia especially in relation to hard work making them know that the second coming of the Lord would not be immediate and that such could not suggest cessation from normal living, as declares Gundry (1981, 258), Paul urged them to return to their businesses for such would not have heard or received any such thing from him (cf. 2 Thess. 3:8-9). Thus, the passage was particularly on the apostle's directives and model style of life with respect to disorderly elements within the community.

\section{Analysis of the Text (2 Thess. 3:6-10)}

As has been indicated above, some members of the new community, perhaps because they thought the parousia spoken of by Paul as imminent "or the new age of the Lord to be already here (2:2), had apparently ceased to work for a living"(Senior, 1990: $331)$.

V6 In three strong terms, $\sigma \tau \varepsilon \dot{\lambda} \lambda \lambda \varepsilon \sigma \theta \alpha 1$, $\tau \alpha \dot{\alpha} \kappa \tau \omega \varsigma$, and $\pi \alpha \rho \alpha ́ \delta o \sigma \imath v$, Paul commanded the church to deal decisively with those members acting contrary to the example he had given. Conventionally, the term $\sigma \tau \varepsilon \dot{ } \lambda \lambda \varepsilon \sigma \theta \alpha$, stenlesthai a deponent verb 
from its present active indicative form $\sigma \tau \varepsilon \lambda \lambda \omega$, stenlo meaning to keep one's distance, to keep away or stand aloof from someone as in the verse under review. It could also mean to shun, avoid or try to avoid (Bauer, 2000:942). Paul here commanded the church to avoid any loafer in the system because such were walking in

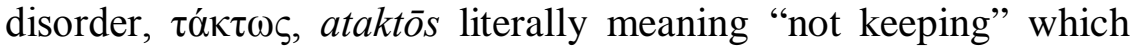
"was especially a military term, denoting not keeping rank, insubordinate," here, not keeping ranks denotes slackness and in this context, it manifests itself in refusal to work in order to earn a living contrary to the culture of industry which Apostle Paul led while he was with them. Also, the term $\pi \alpha \rho \alpha$ ó oov, paradosin translated "tradition" in this verse according to Vine "is used of instruction concerning everyday conduct" implying that hard work is a sine qua non for morality authenticating the common saying “an idle mind or person is a devil's workshop" (Vine, 1996:174).

Any evil (known or unknown) is possible with such a person whereas a busy man minds his businesses and makes positive contributions to the growth and development of the society. Although one cannot conclude at this point of the work, but it is compelling as well as important to say that the writer, Paul was here very imperative in his tone as regards idleness and the attendant results and would not encourage such. The three functional words used to rebuke the attitude are commanding in nature showing his mind about it and the menace of it. This hard work tendencies, of course, addresses the issues of laziness as well as corrupt practices whether in the government or among the ordinary man in the street. Leaving on or tampering with public fund, or any public belongings on the part of those in power could be likened to the idle man in the street who either robs and does pickpockets or the armed robber who goes about collecting peoples' things at gun-points. Such will always destroy the system 
and such has been the case in the nation for as long as one can remember.

Vv7-8 The word translated labour is the same rendition in virtually all the versions one reads it. In RSV, (Revised Standard Version), for instance, the rendition tallies with the view of Bauer, in these two verses. Paul here recalled his personal attitudes to life during his stay in Thessalonica. He never loafed or depended on others to supply him with free food (v8). He rather supported himself in spite of much fatigue ("labouring and toiling," v8) with many obstacles (cf. 1 Thess. 2:9) in order to relieve the infant church in Thessalonica of the burden to support him. The term ко $\pi$, kop $\bar{o}$ according to Bauer, means "to engage in activity that is burdensome, work, labour, and toil" (Bauer, 2000:942) and Paul engaged himself in such that the work of God under his custody, and Christianity at large would not suffer shame. Asking them to imitate him was more like asking them to imitate Christ (1 Thess. 1:6) because Paul's life was so carefully patterned after his Lord's (Thomas, 2006:481).

Paul was therefore right to ask them to emulate his good example as he had emulated Jesus' lifestyle but very few Nigerian leaders or almost none, whether sacred or social, can boldly make such statement without being guilty of hypocrisy. It has been a culture of the might eating up the vulnerable and daring them and all they could imagine. Like some say, idleness or laziness a trait that is alien to Nigeria because Nigerians are naturally hard working but if people are perceived lazy, the society especially the ruling class has some questions to answer particularly given that nothing works in the land.

V9 In this verse, Paul disclosed his intentions for his personal discipline. He purposed to give them the example they must follow. Thus, he said "not because we do not have that right, 
but to give you in our conduct an example to imitate." In other words, you Thessalonians, it is not that we do not deserve the right to induce you to give for our upkeeps (cf. 1 cor. 9:4-27; 1 Thess. $2: 7$ ), but we would not because we intended to teach you dignity in labour. Like Jesus, he and his associates did that for the sake of being good examples Nwanguma, 2014:53). It could be possible that Paul and his associates must have seen the trait of idleness and depending on others among the people and would want to discourage such. He would have noticed the consequence of such (depending on others) on the society especially their economy.

V10 Paul here reinforced the tradition of the church (cf. Gen. 3:19, 1 Thess. 2:9-12) earlier made known to them and commanded that if eventually any shuns to work, the same should be made to starve, that is, no one must be tempted to show him mercy by rendering him help of any sort because such would affect the society adversely in the long run. This could be called the climax of the whole exhortation. This author calls it Paul's "economic and social concerns" Nwnguma, 2014) in an earlier work of his. Christianity is a religion that is heavily characterised with hard work and the same enhances economic and social development and such most probably explains why most Christian nations and states have always been economically and socially developed over ages.

\section{Application to the Modern Man and Nigeria in Particular}

One may perhaps be forced to ask of what relevance is this (Paul's hard work) to the modern man in Nigeria and anywhere in the world? Or, of what significance is Christian Studies, or Religious Studies as a whole to the society? Just a quick glance through the passage analysed and the analysis itself together with all that is done so far answers this question. 
From the very outset, Paul's instruction or command to the church he planted at Thessalonica was "keep away from any member who loafs about violating the tradition they received from him and his associates" (v6). Idleness is an attitude or character which Christianity frowns at with passion. Citing his own example "while he was with them," he narrated "how he was not idle and earned his living through his own labour though he had right to depend on them as those who benefited from his spiritual services (1 Cor. 9:8-15) (Nwanguma, 2014). The reason was simple; neither Paul nor his associates would want to be burdens to the new church that had just been established.

Apart from not being willing to constitute oneself nuisance in the society, another serious reason for this was that of economic and social welfare of the society - if all would get engaged in legitimate activities to earn living, the society will be an enviable one (such that flows with milk and honey) where all will desire to be. This was particularly what informed the kind of activities the early missionaries in Africa and Nigeria in particular engaged themselves with. For example, part of their total commitments to effect changes in spiritual and ethical lives of the African society was also to affect their socio/economical well-beings. This they did by establishing different training programmes such as Theological Institutes or Seminary Schools where would-be Pastors or Priests were trained Yusufu, 1999:285), primary and secondary schools, and later tertiary institutions where leadership skills could be developed, and skill acquisition centres where artisans could gain some skills that would enable them contribute positively to the economy of the land (Nwanguma, 2014:25). Entrepreneurship which is now the order of the day in schools and stylishly being credited to Management Studies was one of the core values of the missionaries and it stemmed from insights gained from Sunday 
Schools and Pulpit Proceedings (Yusufu, 1999) from the Pauline model of industry and the same was called his "tradition." And by such (entrepreneurial activities) which was eventually overlooked and consciously or unconsciously disbanded by some governments of some nations, especially in Africa, the church/missionaries developed nations in all regards. In this connection, it will be pertinent to state the agenda of the Justice Development and Peace Commission (JDPC) programme of the Roman Catholic Mission which is reminiscent of activities in most Christian denominations within and outside the country as listed by Achunike. They are:

1. To promote quality of people;

2. To promote human rights (e.g. U.N. Charter on Human Right and Benjul Declaration on Human Rights);

3. To form and animate groups to participate in their own development;

4. To make preferential option for the poor and marginalized

5. To research, document and publish information on social issues;

6. To build channels of dialogue through actions of Justice and Peace (Achunike, 2004:133-134).

Further to this, it is on record that the enlightenment the modern Africans are enjoying today is a by-product of the education brought to them by these missionaries; and the same aided and enhanced production of manpower for the much needed goods and services for the societal well-being. Thus, in the accounts of Hildebrandt (1981) and Ejiogu (1986), Christianity came to Africa and other parts of the world through Europe by means of policies of Portuguese, French, and British governments to liberate the dark minds of barbaric (socially and economically backward, emphasis mine) Africans and other such parts of the world. Ejiogu in 
particular writes that they (missionaries) adopted the policy of "conversion through education" and "evangelism through education" according to Ejiogu (1986) as the case might be depending on which mission was in charge, whether Catholic or Protestant mission. In his word:

Enculturation is attempt to plant the Christian life and Christian message in a particular culture context in such a way that this experience not only find expression through elements proper to culture in question but becomes a principle that animates, directs and unifies the culture, transforming it into a new creation.

This enculturation programme which resulted in new species of persons in those who benefited from it further metamorphosed to well principled, mannered, well-behaved educated Africans who became the first set of leaders in the society. Thus, Africa and Nigeria in particular got well trained through this tradition of hard working handed down by St Paul and such enhanced development socially and economically. It is then disheartening that this handmaiden of the Lord, Christian teaching, which metamorphosed to Christian Studies is pathetically despised and blackmailed. Many derogatory words have been used to run it down as well as making it unpopular in the society across the globe which was once referred as queen as science.

\section{Conclusion and Recommendations}

What this author has hitherto addressed, centrally, has been Paul's theme in his letter to the Thessalonian Church especially as documented in 1 Thessalonian 3:6-10. This informed the technical and deliberate inclusion of the background to the letter and that of the passage under review in particular. As pointed out in the 
analogous imagery of the diffident development stages in a child in the introduction above, and the necessary timely interventions of all concerned to effect the desired change in the child's developmental processes; so have the appropriate quarters been appealed to in the course of this work in order to ensure the desired change in the nation.

As indicated above, nothing could be destructive as idleness. It has been strongly argued that the root cause of the various vices in the land is this cancerous evil. According to Parsons, "idleness leads to this evil imagination. Bored people seek diversions for their boredom, often leading to perversions in order to entertain themselves. They then neglect godly duties." (Parsons,www.ChristianUniverse.com/sermon/idleness ). Godly duties as far as this writer is concerned, are any endeavour that is capable of building oneself and the wider society. Angry at the writings of most Africans on the negative and disdaining attitudes of the whites towards Africa and Africans in a class section on a topic in African Philosophy, this writer asked, have Africans made any deliberate effort to prove the west wrong. Why? It is on record that one time Prime Minister of Great Britain, Mr. Tony Blair, expressed great shock and surprise at Nigerians on realizing that a Nigerian leader had several hundreds of thousands of sterling pounds to squander in his nation and consequently said that he had not handled a hundred thousand pounds of his own since he was born. This was a Prime Minister. But the leader in question was just a mere state governor. Could one please tell what will constrain such a man to call such a people human beings? The only thing that could lead to that is nothing but idle-mindedness. If the leaders had engaged their minds with ideas and thoughts to build a worthwhile nation that everyone everywhere in the world would want to be, they should hardly have enough to spend on the 
worthwhile projects let alone having the ones to embezzle. In the same token, irresponsible parents will certainly breed irresponsible children unless if perhaps something extra ordinary happens. None payment of workers' salaries, poor or none equipment of schools, poor infrastructure, etc. have been the other of the day. And the resultant effect of such hitherto has been abject poverty; miscreant activities on the part of the angry youths who feel highly denied and disappointed by the irresponsible adults, militancy, etc.; and where such is in place, development of any kind (social, economic, political, etc.) will be difficult and sincerely speaking, quite impossible as is the case in Nigeria.

The recommendation therefore is that concerted efforts should be made by Nigerians as to arrest this ungodly situation. Those of stature, independent Christian lawyers and others, who are unhappy with the happenings in the nation, should for instance, endeavor to litigate the governments at all tiers and not just wait for their own turns to get into the public office and even do worse than any has ever done as the case has been. The injunction here is that the church should back up its prayers with commensurate actions, and such has to involve all even where it might mean taking to the streets; and such will bring about the desired change and the development which has for quite a long while been an issue of deliberation anywhere Nigerians gather. If the Nigerian Sunday Adelaja had just stopped at praying without backing the prayers up with some actions such as taking to the streets in Ukraine etc. few years ago, the result they had thereafter would have been absent. If the irresponsible leaders could use the youths for evil ends and end up tactically and tacitly educating them on how to destroy themselves and the entire nation, it is advisable that good people should do the opposite with the same youths for the common goods of all. The youths of Nigeria must not be seen 
being used anyhow again for selfish interests of any evil leader in the country. Paul would do this should he still be alive. One cannot be idle either mentally or physically and rightly claim to be a disciple of Jesus Christ because He is not an idle One in any regard either while on earth or now glorified (cf. John 4:34-35ff; Rom. 8:34, Heb. 7:25).

\section{Chibuzo I. Nwanguma}

Department of Philosophy and Religion

Mountain Top University, Ogun chibuzonwanguma@gmail.com

\section{References}

Achunike, H. C., 2004, "Developing the Nigerian Nation through 'Justice, Development and Peace Commission' of the Catholic Church" in M. I. Okwueze (ed.) Religion and Societal Development: Contemporary Nigerian Perspectives, Lagos: MIP

Adeyeye, F. M., 2008, Fundamentals of Health Education and Road Safety, UNILAG: Lecture Material

Bauer, W., 2000, Greek-English Lexicon of New Testament and Early Christian Literature (3rd ed.), \{rev. by F. W. Danker\}, London: Chicago Press

Baumol, W. J. and Blinder A. S., et al, (eds.), 2006, Essentials of Economics: Principles and Policies, Ohio: Thomson Higher Education

Begg, D.; Fischer, S.; and Durnbusch, R., 2005, Economics (8th ed.), London: McGraw Hill Education 
Dzurgba, A., 2009, Introduction to the Sociology of Religion, Ibadan: John Achers (Publishers) Ltd.

Elliot, S. T., 2000, Educational Psychology: Effective Learning, (3rd ed.), New York: McGrew Hill

Gundry, R. E., 1981, A Survey of the New Testament (rev. Ed.), Grand Rapids: Zondervan

Hendrikson, W. 1976, The Survey of the Bible (4th ed.). Grand Rapids: Book House

Hildebrandt, J., 1981, History of the Church in Africa, Achimota: Africa Christian Textbook Press

Nwanguma, C. I., 2014, "Theology, and Human Development: Issue and Prospects" West Africa Association of Theological Institutions, Vol. 8, No. 2

Nwanguma, C. I., 2014, Biblical Missions and Church Growth Strategies: the Nigerian Examples, Lagos: UNIBLEND NIG LTD

Okeafor, D. 2004, "Religion and Societal Development: A Social Work Perspectives in M. I. Okwueze (ed.) Religion and Societal Development: Contemporary Nigerian Perspectives, Lagos: MIP Persons, B., 2016, "Idleness" retrieved from the web, www.ChristianUniverse.com/sermon/idleness

Senior, D. et al, (eds.), 1990, The Catholic Study Bible, Oxford: Oxford University Press

Thomas, R. L., 2006, "2 Thessalonians" in T. Longman III \& D. E. Garland (eds.) The Expositor's Bible Commentary (rev. Ed.), Grand Rapids: Zondervan

Turaki, Y., 1999, Theory of Practice of Christian Missions: A century of SIM/ECWA History and Legacy in Nigeria 1893-1993 Vol. 1, Nirobi: Int'l Bible Society of Africa

Vine, W. E. 1996, Vine's Expository Dictionary of Old and New Testament Words, Nashville: Thomas Nelson 